\title{
A Study on Growth \& Economic Parameters of Stunted Yearling (Indian Major Carp) Culture Technique in Nine Village Ponds of Angul District, Odisha, India
}

\author{
Rashmi Prabha Mishra ${ }^{1 *}$, Chandra Kanta Mishra ${ }^{2}$, \\ Navin Kumar ${ }^{3}$ and Sudhir Kumar Das ${ }^{4}$ \\ ${ }^{1}$ (Fishery Sc.), Krishi Vigyan Kendra, Angul, Odisha, India \\ ${ }^{2}$ Regional Research Centre, CIFA, Anand, Gujarat, India \\ ${ }^{3}$ Agriculture Coordinator, District agriculture office, Samastipur, India \\ ${ }^{4}$ Department of Fisheries Resource Management, WBUAFS, Kolkata, India \\ *Corresponding author
}

\section{A B S T R A C T}

\section{Keywords}

Earthen ponds,

Harvesting,

Manuring,

Food organisms

\section{Article Info}

Accepted:

12 March 2020

Available Online:

10 April 2020

\begin{abstract}
The experiment was conducted from 28/09/16 to 20/06/17 in nine earthen ponds of 0.8 ha (3 no. ponds), 1.8 ha ( 3 no. ponds) \& 0.4 ha ( 3 no. ponds) of three different villages of Angul district. The aim of this study is to assess the Growth \& Economic parameters of stunted yearling (IMC) culture technique by multiple stocking and harvesting method. In the first phase farmers training was organized among a group of 25 farmers for proper dissemination of technology in different aspects of Pisciculture viz., Preparation of Pond, liming, stocking, manuring, feeding, health management and harvesting. Pre-stocking pond preparation methods are followed i.e. removal of predatory and weed fishes by bleaching powder $(10 \mathrm{mg} / \mathrm{l}$ chlorine) and then basal fertilization ( 3 tonn cow dung and $30 \mathrm{~kg}$ single super phosphate / ha) were carried out before stocking of fingerlings (Jena et al., 2005). For better motivation of the farmers to adopt this new Technology, critical inputs were also provided i.e. fish seed, feed, lime and fertilizers. Regular fertilization schedules were followed as recommended practices for increasing natural fish food organisms production. Three different farming trials were taken i.e. Farmers practice (T1) (Catla : Rohu : Mrigal) fingerlings @ 15000 no./ ha and culture for 09 months in an Extensive manner. In Recommended practice (T2) (Catla: Rohu : Mrigal) fingerlings @ 5000 no. / ha and culture for 06 months in a semi-intensive method \& in another trial Recommended practice (T3) (Catla : Rohu :Mrigal) stunted yearlings @ 5000 no. / ha and culture for 06 months in an Intensive method. Health management aspects were assessed by periodic sampling. Fish yield was recorded after harvesting. About 2.5-3 meter water depth was maintained throughout the study period. Water samples were collected from the ponds on quarterly basis preferably in the morning time and analyzed for important parameters were measured following standard methods (APHA, 2014). Then the data like fish weight (gm), fish yield (Quintal/hectar), average net return and B: C was recorded and analysed using statistical tools like Average mean value and percentage. From the results of the analysis it is found out that mean weight gain of stunted yearlings of IMC were higher in T3 compared to T1 and T2. Net fish yield and income in T2 and T3 were also higher than T1. In the present experiment stocking of IMC stunted yearlings of appropriate size and density in selective culture practice leading to $60.90 \%$ increase in fish yield in Recommended practice T3 (35.4 q/ha) against farmer's practice ( 22 q/ha). Similarly Net profit of Rs. 3.78,580 was obtained from this technology with benefit: cost (B: C) ratio of 4.25 against Rs. 2,10,800 and 3.17 respectively from Farmers practice (T1) due to fast growth rate of fish in the second year of their culture.
\end{abstract}




\section{Introduction}

Majority of the villages of Angul district, Odisha having community ponds and the water bodies are not been utilized properly for fish production due to non-availability of good quality and quantity of seed. Hence stunted fingerlings \& yearlings provide an opportunity for fish cultivation in this type of ponds. Since carps are shown fast growth rate during their second year of culture, now a days ponds are stocked with stunted yearlings (8-12 month-old) of $100-150 \mathrm{~g}$, instead of fry or fingerlings as practiced in the conventional system. The culture of stunted Indian major carps has become established in parts of India because the subsequent growth of the fish is supposed to be rapid (Nandeesha, Dathathri, Krishnamurthy, Vargese, Gangadar \& Umesh 1994).

Stunted yearlings are the individuals which is having slow growth rate, early maturation, small size and their growth is restricted by density-dependent mechanisms and the diminished maximum size is not genetically determined. Typically these yearlings are defined as the fish fingerlings which have over wintered to add size/weight and to increase post-stocking survival in a hatchery, pond or tank. These are suitable stocking material for carp culture because of their higher survival rate. They have shown less vulnerability to predation, disease resistant and can withstand environmental fluctuations; can reach marketable size within a less time period i.e. grow upto 700-800 gm within 2.5 to 3 months leading to higher yield \& income. These are having good market demand as they utilize seasonal grow-out ponds efficiently and the fishes can be sold at a higher price too (Radheysham and Saha, 2009). Multiple stocking and multiple harvesting (MSMH) is a method of composite fish farming, through which fish production can be increased by many folds (6 to 10 ton/hectare/year). The farmers need not to have a big capital to meet the various recurring expenditure of fish cultivation. He has to manage the pond for a maximum period of 4 months, thereafter he starts earning, which is reinvested for purchasing of various items required for further fish rearing. Therefore, the small \& marginal farmers can also take up scientific fish farming with their small resources by adopting this system. There are several other advantages; however, the prime advantage is that the production is much higher than yearly composite fish culture system. Netting in short intervals results in release of noxious gases and mixing of bottom nutrients with surface water, which enhances primary productivity of the pond.

\section{Materials and Methods}

The experiment was conducted from 28/09/16 to $20 / 06 / 17$ in nine earthen ponds of 0.8 ha (3 no. ponds), 1.8 ha ( 3 no. ponds) \& 0.4 ha ( 3 no. ponds) of three different villages of Angul district. The aim of this study is to assess the Growth \& Economic parameters of stunted yearling (IMC) culture technique by multiple stocking and harvesting method. In the first phase farmers training was organized among a group of 25 farmers for proper dissemination of technology in different aspects of Pisciculture viz., Preparation of Pond, liming, stocking, manuring, feeding, health management and harvesting. Prestocking pond preparation methods are followed i.e. removal of predatory and weed fishes by bleaching powder (10 $\mathrm{mg} / \mathrm{l}$ chlorine) and then basal fertilization ( 3 tonn cow dung and $30 \mathrm{~kg}$ single super phosphate / ha) were carried out before stocking of fingerlings (Jena et al., 2005). For better motivation of the farmers to adopt this new Technology, critical inputs were also provided i.e. fish seed, feed, lime and fertilizers. Regular fertilization schedules were followed as recommended practices for increasing natural 
fish food organisms production i.e. @ 2.5-5 qt1/ha. Poultry manure / month \& 3-5 kg. multiplex/ pond culture. Three different farming trials were taken i.e. Farmers practice (T1): (Catla : Rohu : Mrigal) fingerlings@15000 no. / ha and culture for 09 months in an Extensive manner. In Recommended practice (T2): (Catla : Rohu :Mrigal) fingerlings @ 5000 no. / ha and culture for 06 months in a semi-intensive method \& in third trial / Recommended practice (T3): (Catla : Rohu :Mrigal) stunted yearlings@ 5000 no. / ha and culture for 06 months in an Intensive method. Stunted yearlings were fed with@7.5 kg Ground nut Oil cake $(\mathrm{GNOC})+15 \mathrm{~kg}$ Rice bran $(\mathrm{RB})$ on $1^{\text {st }}$ month, @ $10 \mathrm{~kg} \mathrm{GNOC}+20 \mathrm{~kg}$. RB on $2^{\text {nd }}$ month \& @ $12.5 \mathrm{~kg}$. GNOC + $25 \mathrm{~kg}$. RB on $3^{\text {rd }}$ month. Feed was provided with the help of gunny bags hanging at regular intervals of fish pond.

A commercially available multiplex / vitamin mineral mixture was applied @ $3 \mathrm{gm} / \mathrm{kg}$ fish feed which is beneficial for enhancing plankton quantity in the fish pond. Salt was also added @ 0.5 to 2 percent along with the feed for better fish growth (Gangadhara et al., 2012). Health management aspects were assessed by periodic sampling. Fish yield was recorded after harvesting. After every harvesting 10-15\% water exchange was also done and then again filled the pond with freshwater with the help of 100 mesh size screen net. At the beginning / 1 st week of October and January month, lime was applied @ 100-200 kg/ha \& on the second month of every cropping system, CIFAX was used @ 1 lit/ha-mt. About 2.5-3 meter water depth was maintained throughout the study period. Water samples were collected from the ponds on quarterly basis preferably in the morning time and analyzed for important parameters were measured following standard methods (APHA, 2014). Then the data like fish weight (gm), fish yield (Quintal/hectar), average net return and $\mathrm{B}$ : $\mathrm{C}$ was recorded and analysed using statistical tools like Average mean value and percentage.

\section{Results and Discussion}

During the study, the $\mathrm{pH}$ of water varied between 7.21-8.44 with no marked difference among the treatments (Table 1). Dissolved oxygen also did not show marked difference among treatments and remained between 4.09 to $4.16 \mathrm{mg} / \mathrm{l}$. Total Ammonia Nitrogen contents in water varied insignificantly in treatments within a range of 0.32 to $0.37 \mathrm{mg} / 1$. Nitrite and Nitrate did not show any marked deviation among the treatments and ranged between 0.01 to $0.03 \mathrm{mg} / \mathrm{l}$ and 0.13 to 0.16 $\mathrm{mg} / \mathrm{l}$ respectively. The phosphate content varied between 0.2 to $0.23 \mathrm{mg} / \mathrm{l}$. The other water parameters like total alkalinity, free carbon dioxide and hardness did not record any marked trend in the treatments during the culture (Table 1).

Most of the water quality parameters in the selected ponds of Angul district during the experiment were within suitable limits for Carp culture. The similar observations were also reported by other researchers. (Das et al., 2004; Jena et al., 2002a, 2007a; Sahu et al., 2007; Tripathi et al., 2000). It might be due to adoption of proper pre and post stocking management measures as and when required during the study. From the results of the analysis it is revealed that mean weight gain of stunted yearlings of IMC were higher in T3 compared to T1 and T2 (Table 3). Net fish yield and income in $\mathrm{T} 2$ and $\mathrm{T} 3$ were also higher than $\mathrm{T} 1$ (Table 2). In the present experiment stocking of IMC stunted yearlings of appropriate size and density in selective culture practice leading to $60.90 \%$ increase in fish yield in Recommended practice T3 (35.4 q/ha) against farmer's practice (22 q/ha) (Table 2). This is might be due to adoption of multiple stocking and 
harvesting method (MSMH) instead of single stocking practice for stunted Carp yearling culture. (Jena et al., 2002 \& Hand book on fisheries statistics.2014). In MSMH method stocking as well as harvesting is done for more than once in a year. Important measures adopted for MSMH are stocking of yearlings by stunting the growth of fish seed during first year, restocking and performing multiple harvesting after the fishes attain a size of nearly 250-500 grams (Anon, 2010).

Similar findings are obtained from Andhra Pradesh by stocking with stunted fingerlings (yearlings and "zero point") at the rate of 5000 nos. ha ${ }^{-1}$ (Jayasankar and Das, 2017). Stunting is a phenotypic change appears due to unfavourable environmental conditions, such as overcrowding and limited food accessibility (Noakes and Balon 1982; Björnsson et al., 2007). Several ecological factors, including increased survival from reduced predation and decreased food availability, may influence the development of individuals in stunted populations (Ylikarjula et al., 1999; van Kooten et al., 2007). This stunted growth in 1st year is might be due to Resource limitation (arising from intraspecific density dependence) sizeor age-dependent survival probabilities. Fish whose growth was arrested as juveniles under controlled conditions can subsequently compensate growth when they get suitable conditions. Level of this compensation is mediated by the quality of the grow-out environment (Ylikarjula et al., 1999). Similarly Net profit of Rs. 3.78,580 was obtained from this technology with benefit: cost (B: C) ratio of 4.25 against Rs. 2,10,800 and 3.17 respectively from Farmers practice (T1) due to fast growth rate of fish in the second year of their culture (Table 4). This fast growth is might be due to partial or complete starvation of tropical fish species is followed by a voracious feeding schedule and subsequent restoration of growth resulting favorable conditions during the second year of culture (Nikolsky, 1963).

Table.1 Estimation of Physico-chemical parameters of water for the different treatments during the culture period

\begin{tabular}{|c|c|c|c|c|c|}
\hline \multirow[t]{2}{*}{ Parameters } & \multicolumn{3}{|c|}{ Treatments } & \multirow[t]{2}{*}{ Minimum } & \multirow[t]{2}{*}{ Maximum } \\
\hline & $\begin{array}{c}\text { Farmers } \\
\text { practice }\left(\mathbf{T}_{1}\right)\end{array}$ & $\begin{array}{c}\text { Recommended } \\
\text { practice }\left(\mathrm{T}_{2}\right)\end{array}$ & $\begin{array}{c}\text { Recommended } \\
\text { practice }\left(\mathbf{T}_{\mathbf{3}}\right)\end{array}$ & & \\
\hline $\mathbf{p H}$ & $7.63 \pm 0.54$ & $7.71 \pm 0.63$ & $7.70 \pm 0.62$ & 7.21 & 8.44 \\
\hline Dissolved Oxygen (mg/l) & $4.13 \pm 0.036$ & $4.12 \pm 0.015$ & $4.13 \pm 0.02$ & 4.09 & 4.16 \\
\hline Free Carbon dioxide (mg/l) & $4.11 \pm 0.01$ & $4.10 \pm 0.02$ & $4.09 \pm 0.015$ & 4.08 & 4.13 \\
\hline Alkalinity (mg/l) & $41 \pm 1.0$ & $40.67 \pm 1.53$ & $42 \pm 1.0$ & 39 & 43 \\
\hline Hardness (mg/l) & $37.65 \pm 3.05$ & $38.64 \pm 1.53$ & $37.32 \pm 1.53$ & 35 & 41 \\
\hline Ammonia (mg/l) & $0.32 \pm 0.015$ & $0.32 \pm 0.015$ & $0.33 \pm 0.02$ & 0.32 & 0.37 \\
\hline Nitrite (mg/l) & $0.02 \pm 0.01$ & $0.01 \pm 0.005$ & $0.02 \pm 0.01$ & 0.01 & 0.03 \\
\hline Nitrate (mg/l) & $0.12 \pm 0.01$ & $0.15 \pm 0.01$ & $0.14 \pm 0.01$ & 0.13 & 0.16 \\
\hline Phosphate (mg/l) & $0.21 \pm 0.01$ & $0.20 \pm 0.015$ & $0.22 \pm 0.015$ & 0.20 & 0.23 \\
\hline
\end{tabular}

Values $($ Mean \pm SD) for all treatments differ significantly $(\mathrm{Pb} \mathrm{0.05,} \mathrm{n}=3$ ) 
Table.2 Abstract of fish yield

\begin{tabular}{|l|l|l|l|l|l|l|l|}
\hline $\begin{array}{l}\text { SI } \\
\text { No. }\end{array}$ & $\begin{array}{l}\text { Pond } \\
\text { area } \\
\text { (ha) }\end{array}$ & $\begin{array}{l}\text { Production } \\
\text { from } \\
\text { check } \\
\text { pond (qtl.) }\end{array}$ & $\begin{array}{l}\text { Yield of } \\
\text { check } \\
\text { pond } \\
\text { (q/ha) }\end{array}$ & $\begin{array}{l}\text { Production } \\
\text { from } \\
\text { Demonstrated } \\
\text { pond (qtl.) }\end{array}$ & $\begin{array}{l}\text { Yield } \\
\text { Demonstrated } \\
\text { pond (q/ha) }\end{array}$ & $\begin{array}{l}\text { Production } \\
\text { from } \\
\text { Demonstrated } \\
\text { pond (qtl.) }\end{array}$ & $\begin{array}{l}\text { Yield } \\
\text { Demonstrated } \\
\text { pond (q/ha) }\end{array}$ \\
\hline $\mathbf{1}$ & 0.8 & 18 & 22.5 & 22.48 & 28.1 & 25.52 & 31.9 \\
\hline $\mathbf{2}$ & 1.8 & 48.96 & 27.2 & 67.7 & 37.6 & 83.52 & 46.4 \\
\hline $\mathbf{3}$ & 0.4 & 6.52 & 16.3 & 9.08 & 22.7 & 11.12 & 27.8 \\
\hline & & $\begin{array}{l}\text { Avg. } \\
\mathbf{2 2 . 0}\end{array}$ & & Avg. $\mathbf{2 9 . 5}$ & & Avg. $=\mathbf{3 5 . 4}$ \\
\hline
\end{tabular}

Table.3 Abstract of growth parameters of Carp species

\begin{tabular}{|c|c|c|c|c|c|}
\hline Treatments & $\begin{array}{l}\text { Stocking density } \\
\text { (No./ha) / Culture } \\
\text { Duration (months) / } \\
\text { Method of culture }\end{array}$ & $\begin{array}{l}\text { Avg. Body weight } \\
\text { of Carp (gm) } \\
1^{\text {st }} \text { Crop (October } \\
\text { - December) }\end{array}$ & $\begin{array}{l}\text { Avg. Body weight } \\
\text { of Carp (gm) } \\
2^{\text {nd }} \text { Crop (January } \\
\text { - March) }\end{array}$ & $\begin{array}{l}\text { Avg. Body } \\
\text { weight of } \\
\text { Carp (gm) }\end{array}$ & $\begin{array}{c}\text { Change in } \\
\text { Body } \\
\text { weight }(\%)\end{array}$ \\
\hline FP (T1) & $\begin{array}{l}15000 \text { IMC fingerlings } \\
\text { / } 12 \text { / Extensive }\end{array}$ & 185 & 445 & 232 & - \\
\hline RP (T2) & $\begin{array}{c}5000 \text { IMC fingerlings / } \\
06 / \\
\text { Semi-Intensive }\end{array}$ & 390 & 680 & 443 & 90.94 \\
\hline RP (T3) & $\begin{array}{l}3000 \text { IMC Stunted } \\
\text { yearlings / } 06 \text { / } \\
\text { Intensive }\end{array}$ & 645 & 1070 & 708 & 205.17 \\
\hline
\end{tabular}

Table.4 Abstract of economic analysis of the Farming trial

\begin{tabular}{|l|l|l|l|l|l|l|}
\hline $\begin{array}{l}\text { Technology } \\
\text { option }\end{array}$ & $\begin{array}{l}\text { No. of } \\
\text { trials }\end{array}$ & $\begin{array}{l}\text { Yield } \\
\text { (q/ha) }\end{array}$ & $\begin{array}{l}\text { Cost of } \\
\text { cultivation } \\
\text { (Rs./ha) }\end{array}$ & $\begin{array}{l}\text { Gross return } \\
\text { (Rs/ha) }\end{array}$ & $\begin{array}{l}\text { Net return } \\
\text { (Rs./ha) }\end{array}$ & BC ratio \\
\hline T1 & 03 & 22.0 & 97,200 & $3,08,400$ & $2,10,800$ & 3.17 \\
T2 & & 29.5 & $1,08,400$ & $4,13,000$ & $3,04,600$ & 3.80 \\
\hline
\end{tabular}

From the results of the analysis, it can be are the most preferred stocking material by concluded that: Stunted fingerlings/ yearlings grow out farmers and fetch a higher price than 
the normal fingerlings. Farmers are now able to get an average yield of 8 tonnes/ha and some of the progressive farmers obtain a yield of more than 15 tonnes/ha/year due to high survivability nature of stunted fish (95\%).

Therefore, Successful implementations of this stunted yearling culture technique by multiple stocking and harvesting method will open doors to: make the district self-sufficient in fish production, increase returns on available resources, reduce poverty through Entrepreneurship development, Create employment and income generating opportunities for the rural poor and enhance their food and nutritional security. (Randhir, 1984). It also adds to the foreign exchange earnings of the country (Anjani, 2004) \& generate interest among perspective farmers to adopt yearling production as a lucrative Enterprise.

\section{References}

Anon., 2010: Composite fish culture (Online). Available http://www. nabard. org/ modelbankprojects/ fisheries.asp

APHA., 2014: Standard methods for the examination of water and wastewater (20th ed.) Washington, DC: Author/American Water Works Association/Water Environment Federation. Committee of NACA (FAO/UNDP Project), 3-6 December, Bhubaneswar. 80-86.

Björnsson et al., 2007: Atlantic cod (Gadus morhua L.). In: Le Francois, N.R., Jobling, M., Carter, C., Blier, P. (Eds.), Fish species selection for intensive aquaculture diversification. / Aquaculture 271, 216-226.

Gangadhar, B. and Keshavanath, P., 2012: Growth performance of rohu, Labeo rohita (Ham.) in tanks provided with different levels of sugarcane bagasse as periphyton substrate. Indian Journal of Fisheries, 59: 77-82

Hand book on fisheries statistics. 2014: Department of Animal husbandry, Dairying and Fisheries, Ministry of Agriculture, Government of India, New Delhi, 166.

Jayasankar, P. and Das, P. C., 2015: Vertical expansion strategy for increased freshwater aquaculture production. Fishing Chimes, 35: 44-51.

Jayasankar, P., 2017: Freshwater aquaculture technologies for the second blue revolution: Opportunities for aquaculture entrepreneurship. In: Sinha, V. R. P., Gopal Krishna, Keshavanath, P. and Kumar, N. R. (Eds.), Social entrepreneurship in aquaculture. Narendra Publishing House, New Delhi, India, p. 147-158.

Jena J. K., Ayyappan, S., Aravindakshan, P.K., 2002: Comparative evaluation of production performance in varied cropping patterns of carp poly culture systems. Aquaculture, 207, 49-64.

Jena JK, Das PC, Das R, Mondal S., 2007: Performance of olive barb, Puntius sarana (Hamilton) in fingerling rearing with rohu, Labeo rohita (Hamilton) and mrigal, Cirrhinus mrigala (Hamilton), Aquaculture ; 265:305-308.

Kumar, Anjani., 2004: Export performance of Indian Fisheries - Strength \& challenges ahead. Economic and Political Weekly, XXXIX: 4264-4270

Nandeesha, M.C., K. Dathathri, D. Krishnamurthy, T.J. Varghese, B. Gangadhar and N.R. Umesh., 1994: Effect of varied level of protein on the growth and tissue biochemistry of stunted yearlings of rohu Labeo rohita in the absence and present of natural food. Fish nutrition research in Asia. Proceedings of the fifth Asian Fish Nutrition Workshop, Silva, De. S.S.(ed.), (9): 93-100. 
Noakes, D.L.G. and E.K. Balon., 1982: Life histories of tilapias: an evolutionary perspective. pp. 61-82. In: R.S.V. Pullin \& R.H. Lowe-McConnell (ed.), The Biology and Culture of Tilapias. ICLARM, Manila.

Radheysham, De, H. K. and Saha, G. S., 2009: Role of community in production of larger and quality fingerlings. Aquacult. Asia Mag., 14:16-17.

Randhir, M., 1984: Economic analysis of composite fish culture. In: Report of Fourth Advisory

Sahu, P.K., Jena, J.K., Das, P.C., Mondal, S., Das, R., 2007: Production performance of Labeo calbasu (Hamilton) in polyculture with three Indian major carps Catla catla
(Hamilton), Labeo rohita (Hamilton) and Cirrhinus mrigala (Hamilton) with provision of fertilizers, feed and periphytic substrate as varied inputs.

Tripathi SD, Aravindakshan PK, Ayyappan S, Jena JK, Muduli HK, Chandra S et al., 2000: New dimensions in intensive carp polyculture in India. J. Aquac. Tropics.; 15(2):119-128.

Van Kooten, T., L. Persson and A. M. De Roos., 2007. Size-dependent mortality induces life-history changes mediated through population dynamical feedbacks. American Naturalist 170: 258- 270.

Ylikarjula, J., Heino, M. and Dieckmann, U., 1999. Ecology and adaptation of stunted growth in fish. Evolutionary Ecology 13: 433-453

\section{How to cite this article:}

Rashmi Prabha Mishra, Chandra Kanta Mishra, Navin Kumar and Sudhir Kumar Das. 2020. A Study on Growth \& Economic Parameters of Stunted Yearling (Indian Major Carp) Culture Technique in Nine Village Ponds of Angul District, Odisha, India. Int.J.Curr.Microbiol.App.Sci. 9(04): 1414-1420. doi: https://doi.org/10.20546/ijcmas.2020.904.168 